\title{
Determinants of world trade stagnation in three regions
}

\author{
Sri Indah Nikensari \\ Department of Economics, Universitas Negeri Jakarta, \\ Indonesia \\ indahnikensari@unj.ac.id \\ ORCID 0000-0002-0413-655X \\ Nindya Farah D Puspitasari \\ Department of Accounting, Universitas Terbuka, \\ Indonesia \\ nindyafarab@ecampus.ut.ac.id \\ ORCID 0000-0001-9327-2045
}

\section{Andryan Setyadharma}

Department of Economics, Universitas Negeri Semarang,

Indonesia

andryan@mail.unnes.ac.id

ORCID 0000-0002-7248-7925

\section{Nirdukita Ratnawati}

Department of Economics, Universitas Trisakti,

Indonesia

nirdukita08@gmail.com

ORCID 0000-0002-1053-9339

Abstract. Sharp decline in the world trade occurred again, after in 2018 it had increased, not least in the countries of free trade areas. This empirical study aims to map and compare the factors that influence export and import performance in the regions of Southeast Asia (AFTA), Europe (EEA), and Latin America (LAIA) before the Covid-19 pandemic crisis. The data has been collected from various sources of both official and private institutions for the time period of 2011-2019. Multiple regression analysis of panel data is used to provide greater and more informative observations and reduce the collinearity of the independent variables. The results show that the performance of exports and imports in the three regions in question shows a stagnant trend and is likely to decline in 2019, especially in part of exports performance. In all the regions in question, export performance is influenced by strengthening or weakening of the real effective exchange rate (REER) and the number of manufactured products, while import performance is more influenced by GDP per capita and REER too. Several other independent factors were also studied, but they did

Received: March, 2020 1st Revision: March, 2021 Accepted: May, 2021

DOI:

$10.14254 / 2071$ $8330.2021 / 14-2 / 10$ 
not affect all the regions under consideration equally. For example, competitiveness rate affected exports in the EEA and LAIA but not in AFTA, while the consumer confidence rate affected imports in AFTA and LAIA but not in the EEA.

Keywords: international trade, stagnation, free trade area, demand factors, supply factors, exports, imports.

JEL Classification: F02, F14, F15, F17, C33, C51

\section{INTRODUCTION}

Until the end of 2019, world trade was still showing weakening after the 2018 increase, and then it was falling again until the end of 2020, it is likely to record weakening again, similar to 2010 and 2016. This is partially due to the unresolved trade war between the US and China, and also the effects of the Covid-19 epidemic. The trade war has caused the GDPs of the US and China to decline (Itakura, 2020), because this war caused the demand for products between these two big countries to decrease, which in turn caused a decrease in economic activity, and had a global impact, before the two countries shifted their trade interests to other countries. The Covid-19 pandemic has exacerbated the decline in demand for all the products due to restrictions on the movement of people and goods between countries, so that trade volumes have dropped (Del Rio-Chanona, Mealy, Pichler, Lafond, \& Farmer, 2020).

Entering 2021, the world trade has not shown a meaningful recovery. The cause of the current weakening of global trade seems to be different from what happened in Europe back in 2010, which has been analysed as a cycle rather than a decline in global economic activity due to the fact that more "tradeintensive" GDP components - such as private investment, consumption of durable goods, and inventory - have experienced a greater change than goods and services that are not traded during the business cycle. But after that, the slowdown in the volume of world trade including Europe did not improve rapidly until the end 2018, and it had caused a slowdown in economic growth to a lower and even negative level. One of the causes for the decline in the volume of world trade to date may have been a decrease in demand from large countries such as China and the United States, because both countries experienced a slowing down economic growth. The financial condition of Asian countries also contributed to a slowdown in economic growth of China.

Some researchers claim that slowdown in the world trade on the demand side is related to income, changes in trade structure and aggregate demand (Constantinescu, Mattoo, \& Ruta, 2015), decline in global economic growth and changes in the structure of the world economy (Lewis \& Monarch, 2016), declining growth in imports from China (Hong, Lee, Liao, \& Seneviratne, 2017).

Slowing trade activities also occur in several regional free trade areas (Free Trade Areas). Based on the WTO data, export activity in Asian developing countries declined in 2015, while in South Asia countries the negative growth was observed, whereas in developed countries and in the European region in particular, a sharp decline in export activity occurred in 2016. In 2019, according to the WTO data, there were many disputes and frictions in trade between countries, but they had little effect on international trade, because disputing countries usually simply transfer their trade to other countries. Whereas on the supply side, the causes of weakening world trade are, among others, related to declining competitiveness (Safeer, 2019), innovation (Ang, Madsen, \& Robertson, 2015; Cassiman \& Golovko, 2011), foreign investments (Mohanty \& Sethi, 2019; Mukhtarov, Alalawneh, Ibadov, \& Huseynli, 2019), research \& development (Falk \& de Lemos, 2019; Lipsey, Blomström, \& Kravis, 2019). 
To date, there have been quite many studies on international trade, including those on slowing down of the global trade activities, but research studies comparing between regions, between time periods and influencing factors is still underrepresented. This study aims to compare and analyse the factors that affect the slowing down of the global trade, on both supply (export) and demand (import) sides, in the countries in the three trade regions - AFTA (ASEAN free trade area), EEA (European Economic Area), and LAIA (the Latin American Integration Association) in the time period of 2011-2019, a period that was more stable than before and after it. In this study, the factors examined from the supply side are the level of innovation, competitiveness, manufacturing production, and real effective exchange rate, while the demand side is represented by per capita income, consumer confidence, real effective exchange rate and economic growth.

Some of the benefits that can be obtained from this research theoretically stem from the comparison of the causes behind the weakening of the world trade activity between free trade areas, which is likely to repeat itself in the future.

This paper is organized as follows. The introduction describes the background and the importance of the study on stagnation in the world trade, followed by the review of literature relevant to this topic. Then goes the explanation of the research methods, including how the data collected from the three free trade areas will be analysed. The results and discussion are summarized in the next part, finally, conclusions are presented at the end of this research study.

\section{LITERATURE REVIEW}

Mercantilist School highlighted the importance of the international trade surplus for the country's prosperity. Adam Smith emphasized the theory of absolute excellence where there is specialization, efficiency, and division of labour in production so that the State has an advantage in international trade. David Ricardo emphasized the theory of comparative advantage, of taking the other side for a State that does not have absolute superiority. JS Mill continued David Ricardo theory, which used the length of working hours needed as a benchmark to assess the comparative advantages of two countries regarding international trade. The new international trade theory that emerged around the 1970s emphasized the achievement of economies of scale using companies that export goods. In other words, export activities can be carried out by companies if companies are able to produce certain fixed costs for large economies of scale or utilise labour with certain skills to produce goods on a large scale.

The opinions of the above experts are aimed at increasing exports. However, export performance is sometimes unpredictable due to uncertainty regarding the future. This uncertainty creates a theory regarding the business cycle or economic cycle, which describes how the performance of the economy sometimes expands, reaches a peak, undergoes recession or even depression, reaching the deepest troughs before finally starting to recover. Mainstream economists argue that the business cycle is caused by exogenous factors or from factors on the supply side, while the Keynesian school views the cause of the business cycle as being changes in factors that are endogenous or from the demand side (Haberler, 2017). However, lately, another name for the term business cycle has emerged: economic fluctuations due to shocks. Economic fluctuations, which represent a new paradigm, combine the sources of fluctuation from changes in both the demand and supply sides (Cerra \& Saxena, 2017).

\subsection{The role of the free trade area}

According to the OECD (1999), regional trade agreements are agreements between the government to liberalise trade and possibly coordinate other trade activities. There are four main types of regional trade arrangements: Free Trade Area, Customs Union, Common Market, and Economic Union. Joe Myers 
from the World Economic Forum (2016) stated that, currently, there are around 420 regional trade agreements, but not all of them are free-trade zones. Grossman (2016) stated that one of the reasons for the establishment of regional trade liberalization areas is the necessity for trade between countries in a region to be tariff free to maximize welfare. Another opinion is that some of the reasons for the existence of regional trade agreements are for use as a foundation for strategic alliances, as part of security arrangements (as in Europe), to gain access to larger markets (as in Canada and the United States), to secure domestic markets, to aid in policy reform (Mexico in NAFTA), and to influence the next multilateral negotiations (Whalley, 2007).

\subsection{Demand and supply side of international trade}

Global trade aims to minimize the existence of barriers in trade activities between countries/regions that make trade agreements. Global trade is often referred to as trade globalization or free trade, adhering to free market understanding. The export and import activities of a country are influenced by foreign demand and domestic offers or conditions that affect production activities. According to Romero and McCombie (2018), exports and imports are affected by the income elasticity of demand and the non-price elasticity of demand due to differences in quality and non-price competitiveness.

In general, a decline in world trade activity is caused by the demand and supply side conditions. The demand side conditions include the prices of traded goods and their substitution prices, income, tastes, and so on, while the supply side conditions include the prices of goods traded, input prices, and technology.

\section{(1) Demand side}

In the theory of demand, the demand for goods/services by foreign countries is generally influenced by the price of goods, the prices of substitute goods, income, and consumer tastes:

$$
Q D x=f(P x, P y, \text { Incone, Taste, } \text { etc })
$$

In the context of global trade, these factors can include the economic conditions in other countries that import goods and services, so the factors that affect imports include the Gross Domestic Product (Adewuyi, 2016), the income per capita (Markusen, 2013), consumer confidence (Grimme, Lehmann, \& Noeller, 2021; Pascucci, 2018), the purchasing power parity (Taylor \& Taylor, 2004), the exchange rate (Kim, 2017; Nishimura \& Sun, 2018), the real effective exchange rate (Liau \& Geetha, 2020), and the shipping waiting time (Fugazza \& Hoffmann, 2017).

In the theory of demand, the demand for goods/services by foreign countries is generally influenced by the price of goods, prices of substitute goods, income, consumer tastes:

$$
Q D x=f(P x, P y, \text { Incone, } \text { Taste, } \text { etc })
$$

By using non-homothetic preference assumptions where the elasticity of income demand is not equal to one, Markusen (2013) states that equality in the per capita income has a positive effect on international trade, while differences in per capita income have a negative effect on international trade. Markusen's research also concludes that if there are two countries with equal growth in total income but only one country that grows in productivity, the trade to GDP ratio of the two countries will increase over time if there is productivity growth in poor countries. 
According to Nishimura and Sun (2018), China's exports to Europe during the reform period were only affected by the EUR to RMB exchange rate per se and not by its volatility. However, both the exchange rate and its volatility significantly affected European exports to China during the reform period. There are slight differences among exchange rates, purchasing power parity (PPP), and term of trade. Exchange rates are the rates at which one currency is exchanged for another, usually using a widely used reference currency such as US dollars, Euros, or RMB. The Real Effective Exchange Rate (REER) is a weighted average of a country's currency in relation to an index or basket of other major currencies, adjusted for the effects of inflation. Weight is determined by comparing the relative trade balance of a country's currency against each country in the index. This exchange rate is used to determine the value of a country's currency relative to other major currencies in the index, such as the US dollar, Japanese Yen, and Euro.

The term PPP is not significantly different from the exchange rate. According to OECD Data (2018), the purchasing power parity (PPP) is a currency conversion rate that equates the purchasing power of different currencies by eliminating differences in price levels between countries. In its simplest form, the PPP shows the ratio of prices in the national currency for the same goods or services sold in various countries. The PPP is also calculated for the product group and for each of the various aggregation levels, including the GDP.

The term of trade is the ratio of a country's export price index to its import price index. The ratio compares export prices to import prices, trade requirements related to the trade balance and balance of payments and can be interpreted as the number of imported goods that can be purchased per unit of exported goods.

\section{(2) Supply Side}

Export activities are also influenced by the supply side or domestic conditions that affect the production of goods and services. Like the supply theory, in general, the supply is influenced by the price, cost of input, technology/innovation level, and capital.

$$
Q S_{x}=f\left(P_{x}, P_{\text {input }}, \text { Tech, Inov, Capital }\right)
$$

Prices can be reflected by the exchange rate as well as the purchasing power parity (PPP). The real effective exchange rate (REER) is the weighted average of a country's currency in relation to an index or basket of other major currencies. The real effective exchange rate (REER) is better than the nominal exchange rate, because it already contains relative price movements between domestic prices and foreign prices (Asteriou, Masatci, \& P1lbeam, 2016).

In the context of global trade, the supply of goods and services is strongly influenced by the domestic economic conditions of those producing goods and services. Factors that influence exports include labour costs (Doulos, Katsaitis, \& Zombanakis, 2020), competitiveness (Chen, Chen, \& Yao, 2020; Ruzekova, Kittova, \& Steinhauser, 2020), manufactured products (Hanson, Robertson, \& Brambilla, 2010), innovation (Ang et al., 2015; Bhat \& Momaya, 2020; Cassiman \& Golovko, 2011; Guan \& Ma, 2003), foreign direct investment (Mohanty \& Sethi, 2019; Mukhtarov et al., 2019), research and development (Falk \& de Lemos, 2019), and the occurrence of crises (Karagöz, 2016). 


\section{METHODOLOGY}

The purpose of study was to compare and analyse the factors that affect the deceleration of global trade on both the supply (export) and demand (import) sides. This study used quantitative data in the form of numbers in the real sense. This study considered the period of trading activity that occurred after the 2008 financial crisis in the United States, which, according to the World Bank, began in 2010, so the data period used was from 2011 to 2019. The panel data used in this study included data originating from the State countries of three trade regions (AFTA, EEA, and LAIA) in the period 2011-2019. Data were collected from various official sources, including the World Bank, World Trade Organization (WTO), International Trade Centre (ITC), and other relevant sources. Regarding the research theme, countries not included in the trade areas mentioned above were not included. Based on the availability of data, the countries in the three free trade zones studied were Indonesia, Malaysia, Singapore, Thailand, the Philippines, and Vietnam (ASEAN Free Trade Area-AFTA); Austria, Belgium, Denmark, Finland, France, Germany, Greece, Hungary, Ireland, Italy, Netherlands, Norway, Poland, Spain, Sweden, Switzerland, and the United Kingdom (European Economic Area-EEA); and Argentina, Brazil, Chile, Colombia, Mexico, and Peru (the Latin American Integration Association-LAIA).

World Bank data on the goods and services exported/imported at a constant price in US\$ billions were included. The level of innovation was measured by the innovation index issued by INSEAD from the Business School of the World. Factors considered to affect exports were the level of innovation, the number of manufactured products, the level of competition, and the level of exchange rates. The number of products manufactured each year at a constant price in US\$ and the level of competition indicated by the Competitive Index issued by the World Economic Forum were also measured. The exchange rate was calculated based on the Real Effective Exchange Rate index $(2010=100)$ issued by the World Bank.

Imports are influenced by the per capita income, exchange rate, consumer confidence, and economic growth. The per capita income was measured as the Gross Domestic Product divided by the population. The exchange rate was measured by the Real Effective Exchange Rate index $(2010=100)$ issued by the World Bank. Consumer confidence was measured by the Consumer Confidence Index issued by The Conference Board through a survey conducted in collaboration with the Nielson institution. Economic growth was measured by the percentage change in real GDP based on World Bank data.

The analytical method used in this study was a quantitative descriptive analysis method involving tables, figures and panel data regression equations. A multiple regression analysis of the panel data was used to provide greater and more informative observations and to reduce the collinearity of independent variables. The panel data regression equations included:

$$
\mathrm{Ex}_{\mathrm{it}}=\alpha+\beta 1 \mathrm{Innov}_{\mathrm{it}}+\beta 2 \mathrm{Mnfac}_{\mathrm{it}}+\beta 3 \mathrm{Comptv}_{\mathrm{it}}+\beta 4 \mathrm{REER}_{\mathrm{it}}+\varepsilon_{\mathrm{it}}
$$

Wheres:

$$
\begin{array}{ll}
\text { EX }_{\text {it }} & \text { - export activity of country } i \text { in year } t \\
\text { Innovit }_{i t} & \text { - innovation index of country } i \text { in year } t \\
\text { Mnfacit }_{i t} & \text { - number of products manufactured by country } i \text { in year } t \\
\text { Comptwit }_{i t} & \text { - competitiveness index of country } i \text { in year } t \\
\text { REER }_{i t} & \text { - real effective exchange rate of country } i \text { in year } t \\
& \text { IM }_{\mathrm{it}}=\alpha+\beta_{1} \text { Ycap }_{\mathrm{it}}+\beta_{2} \text { Growth }_{\mathrm{it}}+\beta_{3} \mathrm{CCI}_{\mathrm{it}}+\beta_{4} \mathrm{REER}_{\mathrm{it}}+\varepsilon_{\mathrm{it}}
\end{array}
$$

Wheres: 


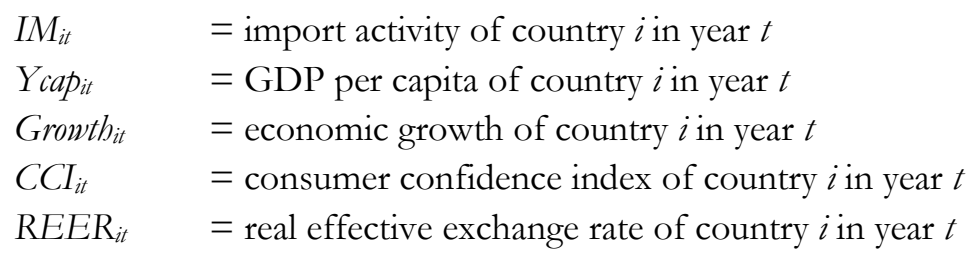

Chow tests and Hausman tests were performed to select the best equation model, fixed effect model (FEM), random effect model (REM), and Pooled Least Squares (PLS)/Common Effect (CEM) model. FEM and PLS/CEM use the Ordinary Least Squared (OLS) approach, while the Random effect uses the Generalized Least Squares (GLS) approach.

According to classical assumptions (Classical Linear Regression Model), the linear regression equation with the Ordinary Least Squared (OLS) approach should not detect any symptoms of multicollinearity, heteroscedasticity, or autocorrelation and must have a normal residual distribution so that the coefficient of linear regression meets the characteristics of the BLUE (Gujarati, 2012). The normality test, tested with Jarque-Bera and Chi-Square values, was used to determine whether the residual value was normally distributed or not. Although this test is not a BLUE requirement and some opinions do not require this condition as something that must be fulfilled, a good regression model should have a normally distributed residual value. Additionally, if the chosen regression equation is a random effect model (REM) or a GLS model, the heteroscedasticity test is not needed, because the GLS has the ability to be neutralized due to violations of the homoscedasticity assumption.

\section{EMPIRICAL RESULTS AND DISCUSSION}

Until 2019, the average performance levels for exports and imports in AFTA and LAIA countries were stagnant and low when compared to those of the EEA, which have tended to increase slightly.

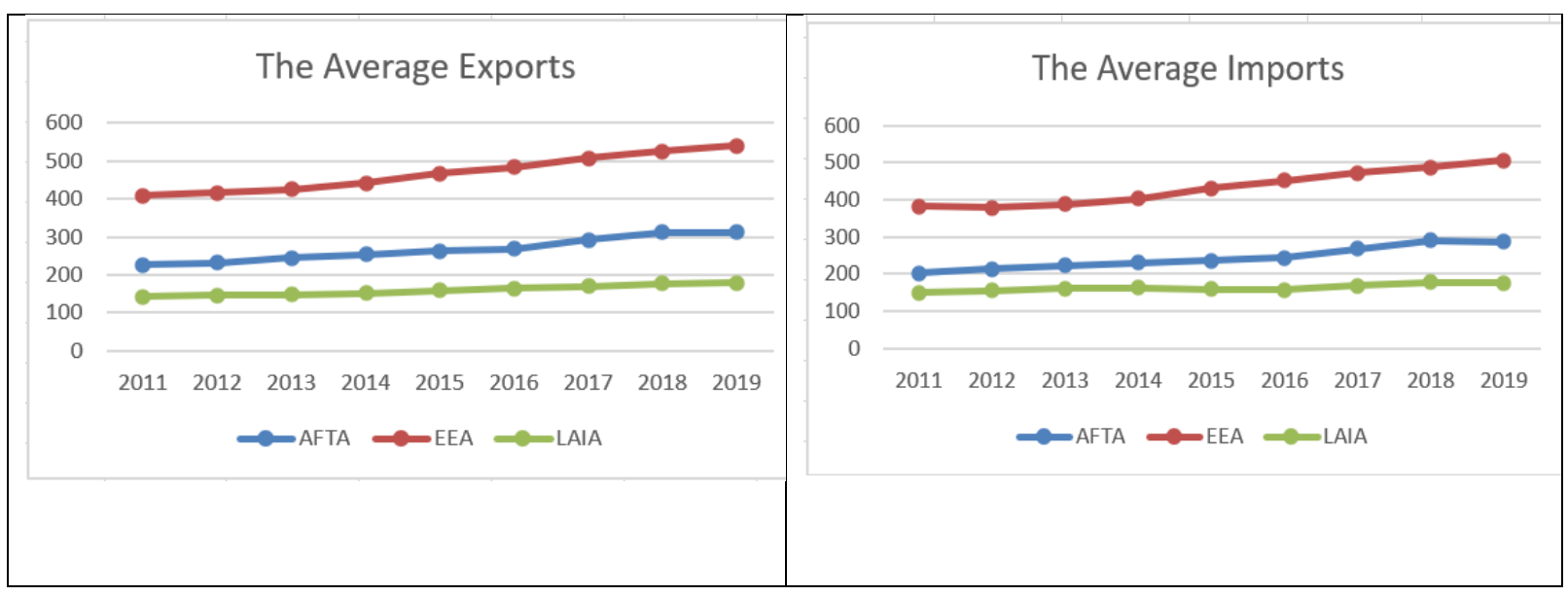

Figure 1. Trends of exports/imports in AFTA, EEA, and LAIA Sources: WTO

Until 2019, the average performance levels of exports and imports in EEA, AFTA, and LAIA countries showed a tendency to stagnate, especially for AFTA and LAIA countries, which have lower than average export levels compared with the EEA. Based on data, the country in the EEA with the greatest level of exports is Germany, and the lowest is Greece. In AFTA, Singapore is the largest exporting 
country, while the Philippines is the lowest exporting country. Mexico and Peru have the highest and lowest average levels of export performance in LAIA. On the import side, the highest and lowest importing countries matched their levels of export performance. Countries with trade deficits in 20112019 were the UK, France, Finland, Greece, Philippines, and Columbia.

The data analysis indicates that some of the factors studied significantly affect the performance of exports and imports in the three regions, but not all trade areas have the same tendency for factors that affect their international trade performance. Table 1 gives the summary of the test results to show the factors that affect the performance of exports and imports in ASEAN countries (AFTA). Table 2 gives a summary of test results for European countries (EEA), and Table 3 gives a summary of test results for Latin American countries (LAIA). Each table illustrates the test results using a selection of the best models, which includes the Chow test, the Hausman test, and the LM test (if necessary), accompanied by the results of the normality test, the results for the detection of classic symptoms (if necessary), and the best panel data regression equation model.

Table 1

Test summary of export and import models in the AFTA countries

\begin{tabular}{|c|c|c|c|}
\hline \multicolumn{2}{|c|}{ Exports } & \multicolumn{2}{|c|}{ Imports } \\
\hline $\begin{array}{l}\text { Chow test: } \\
\text { - prob. c-s F } \\
\text { - prob. Chi-square }\end{array}$ & $\begin{array}{l}0.0000 \\
0.0000\end{array}$ & $\begin{array}{l}\text { Chow test: } \\
\text { - prob. c-s F } \\
\text { - prob. Chi-square }\end{array}$ & $\begin{array}{l}0.0000 \\
0.0000\end{array}$ \\
\hline $\begin{array}{l}\text { Hausman test: } \\
\text { - prob. c-s random }\end{array}$ & 0.0000 & $\begin{array}{l}\text { Hausman test: } \\
\text { - prob. C-s random }\end{array}$ & 0.0002 \\
\hline LM-test: & - & LM-test: prob. B-P & - \\
\hline \multicolumn{2}{|c|}{ Conclusion: The best model is FEM } & \multicolumn{2}{|c|}{ Conclusion: The best model is FEM } \\
\hline $\begin{array}{l}\text { Normality test: } \\
\text { - Jarque-Bera } \\
\text { - prob. }\end{array}$ & $\begin{array}{l}1.6532 \\
0.4375\end{array}$ & $\begin{array}{l}\text { Normality test: } \\
\text { - Jarque-Bera } \\
\text { - prob. }\end{array}$ & $\begin{array}{l}2.5241 \\
0.2831\end{array}$ \\
\hline $\begin{array}{l}\text { Glejser test: } \\
\text { - prob F-statistic } \\
\text { - prob.Obs*R-squared }\end{array}$ & $\begin{array}{l}0.4553 \\
0.4332 \\
\end{array}$ & $\begin{array}{l}\text { Breusch-Pagan-Godfrey test: } \\
\text { - prob F-statistic } \\
\text { - prob Obs*R-squared }\end{array}$ & $\begin{array}{l}0.1629 \\
0.1578 \\
\end{array}$ \\
\hline \multicolumn{2}{|c|}{ FEM: L exports of AFTA } & \multicolumn{2}{|c|}{ FEM: imports of AFTA } \\
\hline Variables & $\begin{array}{c}\text { Fixed Effects } \\
\text { Model }\end{array}$ & Variables & Fixed Effect Model \\
\hline $\begin{array}{c}\text { Constant } \\
\text { t-stat }\end{array}$ & $\begin{array}{c}2.3155 \\
(4.2830)^{* * *}\end{array}$ & $\begin{array}{c}\text { Constant } \\
\text { t-stat }\end{array}$ & $\begin{array}{c}-1803.85 \\
(-6.4667)^{* * *}\end{array}$ \\
\hline $\begin{array}{c}\text { Innov } \\
\text { t-stat } \\
\end{array}$ & $\begin{array}{l}0.0219 \\
(1.6959)^{* *}\end{array}$ & $\begin{array}{r}\text { LYcap } \\
\text { t-stat }\end{array}$ & $\begin{array}{c}331.95 \\
(9.422)^{* * *}\end{array}$ \\
\hline $\begin{array}{c}\text { Mnfac } \\
\text { t-stat }\end{array}$ & $\begin{array}{l}0.0075 \\
(4.1042)^{* * *}\end{array}$ & $\begin{array}{c}\text { Growth } \\
\text { t-stat }\end{array}$ & $\begin{array}{c}-3.937 \\
(-1.552)^{*}\end{array}$ \\
\hline $\begin{array}{c}\text { Comptv } \\
\text { t-stat }\end{array}$ & $\begin{array}{c}0.0337 \\
(1.1279)\end{array}$ & $\begin{array}{l}\text { LCCI } \\
\text { t-stat }\end{array}$ & $\begin{array}{c}81.016 \\
(1.431)^{*}\end{array}$ \\
\hline $\begin{array}{r}\text { REER } \\
\text { t-stat }\end{array}$ & $\begin{array}{l}0.0133 \\
(3.4298)^{* * *}\end{array}$ & $\begin{array}{l}\text { LREER } \\
\text { t-stat }\end{array}$ & $\begin{array}{c}-266.703 \\
(-3.921)^{* * *}\end{array}$ \\
\hline $\begin{array}{l}\mathrm{R}^{2} \\
\text { Adj. } \mathrm{R}^{2} \\
\text { F-stat }\end{array}$ & $\begin{array}{c}0.959 \\
0.951 \\
114.406\end{array}$ & $\begin{array}{l}\mathrm{R}^{2} \\
\text { Adj. } \mathrm{R}^{2} \\
\text { F-stat }\end{array}$ & $\begin{array}{c}0.982 \\
0.979 \\
270.463\end{array}$ \\
\hline
\end{tabular}

Source: Authors' results. ${ }^{* * *}$ sig. $<5 \%$; **sig. $<10 \%$; *sig. $<20 \%$.

In the ASEAN region (AFTA), ten countries are included in the free trade agreement, but only six of these were sampled in this study: Indonesia, Malaysia, Singapore, Thailand, the Philippines, and Vietnam. 
Brunei, Myanmar, Lao PDR, and Cambodia were not included in the sample due to incomplete data availability.

Table 1 shows that, in ASEAN countries (AFTA), the model is a log-lin regression equation for the supply side and a lin-log regression equation for the demand side. Based on the Chow test and the Hausman test, the best model for export and import equations is the Fixed Effect Model (FEM). Based on the results of the normality test, it is known that the residual data are normally distributed. Based on the Glejser test conducted on exports and the Breusch-Pagan-Godfrey test conducted on imports, the models were not found to contain symptoms of heteroscedasticity. In 2011-2019, the export value increased until 2018, but it decreased in 2019. The real effective exchange rate (REER) has a tendency to be weak in some countries. The value of manufactured products (Mnfac) and the innovation index (Innov) tended to increase, while the competitive index (Comptv) increased at the end of the period (2019). On the other hand, the import value and GDP per capita tended to increase, and the Growth and Consumer Confidence tended to increase but then decreased in 2019.

The table shows that if the value of the independent variable approaches zero, the export performance in ASEAN countries will increase. Factors that significantly influence export performance in this region for the 2011-2019 period were the real effective exchange rate (REER) and the value of manufactured products (Mnfac) (sig. $<5 \%$ ). The effect of the innovation index (Innov) was weaker (sig. $<10 \%$ ), and the competition index (Comptv) was shown to have no effect on exports in AFTA. The weakening of REER increased the values of exports $(1.33 \%)$ and manufactured products $(0.75 \%)$, while innovation was also found to have a less significant effect on export performance. The coefficient of determination $\left(\mathrm{R}^{2}\right)$ was 0.98 , indicating that $98 \%$ of the variation in export performance in AFTA countries was influenced by the variables proposed in this study, while the rest of the variation was influenced by variables outside the model. In general, if the independent variables have no influence, the average export performance in ASEAN region countries will be positive. This is shown by the increase in the export performance of all ASEAN countries in 2017-2018, while in 2019, exports decreased slightly, except for from Philippines and Vietnam, where they continued to increase.

On the domestic demand side, the import performance of ASEAN countries (AFTA) showed a slight upward trend but tended to be stagnant. Using the same analysis steps as for export performance, the best equation model was found to be the Fixed Effect Model (FEM). Based on this model, if the influencing factors have no effects, the import performance of countries in the ASEAN region will experience a decline. However, all independent variables investigated in this study were found to significantly improve the import performance of countries in the ASEAN free trade area (AFTA) with different levels of significance. These variables included the GDP per capita (sig. $<5 \%$ ), the real effective exchange rate (sig. $<5 \%$ ), the level of consumer confidence. (sig. $<20 \%$ ), and economic growth (sig. $<20 \%$ ). The GDP per capita has a positive effect on import performance in AFTA countries, which means that if the GDP per capita increases by 1\%, imports will increase by US \$331 million. REER has a negative impact on import performance, meaning that a weakening REER will increasing the import value in AFTA countries by US $\$ 266$ million. Meanwhile, economic growth and consumer confidence have little impact on the demand for imports. The coefficient of determination (R2) is 0.98 , which indicates that $98 \%$ of the variation in changes in exports is influenced by independent variables, while the rest is influenced by other variables that were not examined. The adj. R2 coefficient was also found to be high at 0.97 , showing that all independent variables had significant effects on the import performance.

Meanwhile, 28 members of the European Economic Area (EEA) have agreements with free trade areas, but due to the limited data available for certain countries, our sample only included 17 countries in the region. The 17 countries included were Austria, Belgium, Denmark, Finland, France, Germany, 
Greece, Hungary, Ireland, Italy, Netherlands, Norway, Poland, Spain, Sweden, Switzerland, and the United Kingdom.

In Table 2, the model is shown to be a log-lin regression equation for the supply side, and a log-log regression equation for the demand side in EEA countries. Based on the Chow test, the Hausman test, and the LM test, the best equation model for both the supply/export side and the demand/import side is the Random Effect (REM)/GLS model. Therefore, not all classic symptoms assumption tests commonly found in the OLS regression equation were performed. On the supply/export side, Table 2 shows that all dependent variables significantly influence export activities in European countries (EEA) at different levels and with different effects. Strengthening of the real effective exchange rate (REER) and an increase in the value of manufactured products (Mnfac) are very significant factors in improving export performance (sig. $<5 \%$ ), while the innovation index (Innov) has a moderately significant effect (sig. $<10 \%$ ), and the level of competitiveness (Comptv) has a less significant effect (sig. $<20 \%$ ) on export performance. The coefficient of determination $\left(\mathrm{R}^{2}\right)$ is 0.72 , indicating that $72 \%$ of the change in export activity is influenced by the independent variables studied, while the rest is influenced by variables outside the model. Based on the specification effect, some countries in the EEA region have experienced quite high levels of export performance (France, Germany, and UK), some countries have increased their levels of performance slightly, and half of the countries in the EEA have decreased their exports.

Table 2

Test summary of Export and Import models in the EEA countries

\begin{tabular}{|c|c|c|c|}
\hline \multicolumn{2}{|c|}{ EXPORTS } & \multicolumn{2}{|c|}{ IMPORTS } \\
\hline $\begin{array}{l}\text { Chow test: } \\
\text { - prob. c-s F } \\
\text { - prob. Chi-square }\end{array}$ & $\begin{array}{l}0.0000 \\
0.0000\end{array}$ & $\begin{array}{l}\text { Chow test: } \\
\text { - prob. c-s F } \\
\text { - prob. Chi-square }\end{array}$ & $\begin{array}{l}0.0000 \\
0.0000\end{array}$ \\
\hline $\begin{array}{l}\text { Hausman test: } \\
\text { - prob. c-s random }\end{array}$ & 0.2562 & $\begin{array}{l}\text { Hausman test: } \\
\text { - prob. c-s random }\end{array}$ & 0.0901 \\
\hline LM test: prob B-P & 0.0000 & LM test: prob. B-P & 0.0000 \\
\hline \multicolumn{2}{|c|}{ Conclusion: The best model is REM } & \multicolumn{2}{|c|}{ Conclusion: The best model is REM } \\
\hline $\begin{array}{l}\text { Normality test: } \\
\text { - Jarque Bera } \\
\text { - prob. }\end{array}$ & $\begin{array}{l}5.1946 \\
0.0744\end{array}$ & $\begin{array}{l}\text { Normality test: } \\
\text { - Jarque Bera } \\
\text { - prob. }\end{array}$ & $\begin{array}{l}5.2383 \\
0.0728 \\
\end{array}$ \\
\hline \multicolumn{2}{|c|}{ REM/GLS: L exports } & \multicolumn{2}{|c|}{ REM/GLS: L imports } \\
\hline $\begin{array}{c}\text { Constant } \\
\text { t-stat }\end{array}$ & $\begin{array}{c}4.8018 \\
(4.3322)^{* * *}\end{array}$ & $\begin{array}{c}\text { Constant } \\
\text { t-stat }\end{array}$ & $\begin{array}{c}6.6930 \\
(7.5728)^{* * *}\end{array}$ \\
\hline $\begin{array}{c}\text { Innov } \\
\text { t-stat }\end{array}$ & $\begin{array}{c}0.2886 \\
(1.6630)^{* *}\end{array}$ & $\begin{array}{r}\text { LYcap } \\
\text { t-stat }\end{array}$ & $\begin{array}{c}0.3298 \\
(4.5209)^{* * *}\end{array}$ \\
\hline $\begin{array}{c}\text { Manfac } \\
\text { t-stat }\end{array}$ & $\begin{array}{l}0.5920 \\
(12.4057)^{* * *}\end{array}$ & $\begin{array}{c}\text { Growth } \\
\text { t-stat }\end{array}$ & $\begin{array}{l}0.0015 \\
(0.2920) \\
\end{array}$ \\
\hline $\begin{array}{c}\text { Comptv } \\
\text { t-stat }\end{array}$ & $\begin{array}{c}0.6721 \\
(1.5539)^{*}\end{array}$ & $\begin{array}{l}\text { LCCI } \\
\text { t-stat }\end{array}$ & $\begin{array}{c}0.4784 \\
(7.8739)^{* * *}\end{array}$ \\
\hline $\begin{array}{r}\text { REER } \\
\text { t-stat }\end{array}$ & $\begin{array}{l}-0.8542 \\
(-5.2784) * * *\end{array}$ & $\begin{array}{c}\text { LREER } \\
\text { t-stat }\end{array}$ & $\begin{array}{l}-1.4247 \\
(-7.8619) * * *\end{array}$ \\
\hline $\begin{array}{l}\mathrm{R}^{2} \\
\text { Adj. } \mathrm{R}^{2} \\
\text { F-stat }\end{array}$ & $\begin{array}{c}0.7221 \\
0.7124 \\
740709\end{array}$ & $\begin{array}{l}\mathrm{R}^{2} \\
\text { Adj. } \mathrm{R}^{2} \\
\text { F-stat }\end{array}$ & $\begin{array}{l}0.7391 \\
0.7310 \\
92.068\end{array}$ \\
\hline
\end{tabular}

Source: Authors' results. *sig. $<20 \%$; **sig. $<10 \%$; ***sig. $<5 \%$. The import equation does not include Germany and Greece, because the value of German imports is too high, while the value of Greece imports is too low. 
On the demand side, or for import performance, the best regression equation model for double log panel data is also REM/GLS. Imports in these EEA countries are very significantly (prob $<5 \%$ ) influenced by an increase in the GDP per capita (YCap), a strengthening in the real effective exchange rate (REER), and an increase in the Consumer confidence index (CCI), while the Economic growth (Growth) does not have a significant effect. Based on this, if the YCap increases by $10 \%$, the import value will increase by $3.3 \%$; if the CCI increases by $10 \%$ then the import value will increase by $4.78 \%$; and if the REER strengthens by $10 \%$, then the import value will increase by $14.2 \%$. Strengthening the REER has the greatest influence on imports performance in the EEA. Meanwhile, growth has no effect on the value of imports, because some countries experienced negative growth during the study period, while other countries had positive growth. The coefficient of $\mathrm{R} 2$ is 0.74 , which indicates that $74 \%$ of the variation in changes in imports is influenced by independent variables, while the rest is influenced by other variables that were not examined. The adj. R2 is 0.73 , because one independent variable (Growth) was found to have no effect on the value of imports in the EEA. Growth has no effect on imports performance, because, during the study period, when imports increased, economic growth in some countries was positive, but in some other countries, it was negative.

The third free trade area studied was the Latin American integration association (LAIA). Eleven countries belong to the LAIA, but due to limited data, only six countries were sampled. These countries were Argentina, Brazil, Mexico, Chile, Colombia, and Peru, while the countries not examined were Uruguay, Bolivia, Ecuador, Paraguay, and Venezuela. During the study period, the export value in LAIA countries increased until 2018 but decreased in 2019; Mnfac tended to increase slightly but decreased in some countries (Argentina, Brazil); the REER tended to strengthen slightly or be stagnant; the Comptv tended to increase; and the Innov index was low and volatile. On the other hand, the import value and GDP per capita increased until 2018, but then decreased in 2019, while growth tended to increase but sharply decreased in 2019, even showing negative growth (Mexico). Consumer confidence in some countries increased.

In Table 3, the models shown for LAIA countries are a log-log regression equation for the supply side and a log-lin regression equation for the demand side. Based on the Chow test and the Hausman test, the best model for the exports equation is the Fixed Effect Model (FEM), and for imports equation, it is the REM/GLS. Based on the results of the normality test, it is known that the residual data were normally distributed. Based on the results of the Harvey test on exports and Glejser test on imports, it was determined that the models do not contain symptoms of heteroscedasticity.

Based on the export equation, if the value of the independent variable is zero, then the export performance of countries in the LAIA region will increase. Three factors had significant effects on export performance for the 2011-2019 period, namely, the real effective exchange rate (REER), the value of manufactured products (Mnfac), and the competitiveness index (Comptv), while the innovation index (Innov) had no effect on exports in LAIA countries. The REER was found to decrease the value of exports $(0.36 \%)$. An increase in manufactured products increased the export value $(0.47 \%)$, and an increase in Comptv increased the value of exports (0.14\%). The coefficient of determination (R2) was 0.99 , indicating that $99 \%$ of the variation in export performance in LAIA was influenced by the variables proposed in this study, while the rest was influenced by variables outside the model. 
Test summary of Export and Import models in the LAIA countries

\begin{tabular}{|c|c|c|c|}
\hline \multicolumn{2}{|c|}{ EXPORTS } & \multicolumn{2}{|c|}{ IMPORTS } \\
\hline $\begin{array}{l}\text { Chow test: } \\
\text { - prob. c-s F } \\
\text { - prob. Chi-square }\end{array}$ & $\begin{array}{l}0.000 \\
0.000\end{array}$ & $\begin{array}{l}\text { Chow test: } \\
\text { - prob. c-s F } \\
\text { - prob. Chi-square }\end{array}$ & $\begin{array}{l}0.000 \\
0.000\end{array}$ \\
\hline $\begin{array}{l}\text { Hausman test: } \\
\text { - prob. c-s random }\end{array}$ & 0.000 & $\begin{array}{l}\text { Hausman test: } \\
\text { - prob. c-s random }\end{array}$ & 0.687 \\
\hline LM test: prob. B-P & - & LM test: prob. B-P & 0.000 \\
\hline \multicolumn{2}{|c|}{ Conclusion: The best model is FEM } & \multicolumn{2}{|c|}{ Conclusion: The best model is REM } \\
\hline $\begin{array}{l}\text { Normality test: } \\
\text { - Jarque Bera } \\
\text { - prob. }\end{array}$ & $\begin{array}{l}2.720 \\
0.257 \\
\end{array}$ & $\begin{array}{l}\text { Normality test: } \\
\text { - Jarque Bera } \\
\text { - prob. }\end{array}$ & $\begin{array}{l}5.195 \\
0.074 \\
\end{array}$ \\
\hline $\begin{array}{l}\text { Harvey test: } \\
\text {-prob F-statistic } \\
\text {-prob.Obs*R squared }\end{array}$ & $\begin{array}{l}0.1602 \\
0.1552 \\
\end{array}$ & & \\
\hline \multicolumn{2}{|c|}{ FEM: L exports } & \multicolumn{2}{|c|}{ REM/GLS: L imports } \\
\hline $\begin{array}{c}\text { Constant } \\
\text { t-stat }\end{array}$ & $\begin{array}{l}4.294 \\
(4.914)^{* * *}\end{array}$ & $\begin{array}{l}\text { Constant } \\
\text { t-stat }\end{array}$ & $\begin{array}{c}4.1496 \\
(9.502) * * *\end{array}$ \\
\hline $\begin{array}{c}\text { LInnov } \\
\text { t-stat }\end{array}$ & $\begin{array}{c}-0.044 \\
(-0.230)\end{array}$ & $\begin{array}{l}\text { YCap } \\
\text { t-stat }\end{array}$ & $\begin{array}{c}0.0001 \\
(2.684)^{* * *}\end{array}$ \\
\hline $\begin{array}{c}\text { LMnfac } \\
\text { t-stat }\end{array}$ & $\begin{array}{l}0.475 \\
(2.405)^{* * *}\end{array}$ & $\begin{array}{l}\text { Growth } \\
\text { t-stat }\end{array}$ & $\begin{array}{c}-0.013 \\
(-2.571)^{* * *}\end{array}$ \\
\hline $\begin{array}{l}\text { LComptv } \\
\text { t-stat }\end{array}$ & $\begin{array}{c}0.140 \\
(1.813)^{* *} \\
\end{array}$ & $\begin{array}{l}\text { CCI } \\
\text { t-stat } \\
\end{array}$ & $\begin{array}{c}0.0065 \\
(3.3798)^{* * *}\end{array}$ \\
\hline $\begin{array}{c}\text { LREER } \\
\text { t-stat }\end{array}$ & $\begin{array}{l}-0.356 \\
(-3.951)^{* * *}\end{array}$ & $\begin{array}{c}\text { REER } \\
\text { t-stat }\end{array}$ & $\begin{array}{c}-0.0047 \\
(-2.5712)^{* * *} \\
\end{array}$ \\
\hline $\begin{array}{l}\mathrm{R}^{2} \\
\text { Adj. } \mathrm{R}^{2} \\
\text { F-stat }\end{array}$ & $\begin{array}{c}0.995 \\
0.994 \\
934.07\end{array}$ & $\begin{array}{l}\mathrm{R}^{2} \\
\text { Adj. } \mathrm{R}^{2} \\
\text { F-stat }\end{array}$ & $\begin{array}{c}0.5652 \\
0.5297 \\
15.9230\end{array}$ \\
\hline
\end{tabular}

Source: Authors' results. *sig. $<20 \%$; **ig. $<10 \%$;***sig. $<5 \%$.

On the domestic demand side, the import performance of LAIA countries showed a slight upward trend but tended to be stagnant, and it decreased in 2019. Using the same analysis steps as used to assess export performance, the best equation model was found to be the Random Effect Model (REM). Based on this model, if the influencing factors have no effects, the import performance of countries in the LAIA region will increase. However, all independent variables investigated in this study were found to significantly improve the import performance with a 5\% level of significance. These variables included the GDP per capita, the real effective exchange rate, the level of consumer confidence, and economic growth. GDP per capita was shown to have a positive effect on import performance in LAIA countries, which means that if the GDP per capita increases by US\$ 1 thousand, then the import performance will increase by $0.1 \%$. REER was shown to have a negative impact on import performance, meaning that by strengthening the REER by 10 points, the import performance will reduce by $0.05 \%$. Economic growth has a negative effect on an import performance, which means that if growth increases by $1 \%$, then the import value will decrease by $0.013 \%$. The CCI has a positive influence on import performance, meaning that if the CCI increases by 10 , then the import performance will increase by $0.065 \%$. The coefficient of determination $\left(\mathrm{R}^{2}\right)$ was 0.56 , which indicates that $56 \%$ of the variation in changes in exports is influenced by independent variables, while the rest is influenced by other variables that were not examined.

Based on the trade balance information, several countries experienced deficits throughout the study period, including countries in the EEA (Finland, France, Greece, UK), AFTA (Philippines and Vietnam), 
and LAIA (Columbia and Argentina). If the effects of all independent factors studied were close to zero, the average export and import values in the EEA would still increase. In AFTA and LAIA, the average export value was shown to increase but the average import value was shown to decrease.

Based on the analysis of the factors that affect trade performance in the three regions above, it can be seen that the export and import performance conditions of the three free trade areas are not the same. Table 4 shows that, on the supply side, there are two factors that significantly affect the export performance of the three regions, namely, the number of manufactured products (Mnfac) and the real effective exchange rate (REER).

Table 4

Factors affecting exports and imports

\begin{tabular}{|l|c|c|c|c|c|}
\hline EXPORTS & Constant & Innov & Mnfac & Comptv & REER \\
\hline AFTA & $+* * *$ & $+* *$ & $+* * *$ & 0 & $+* * *$ \\
\hline EEA & $+* * *$ & $+*$ & $+* * *$ & $+* * *$ & $-* * *$ \\
\hline LAIA & $+* * *$ & 0 & $+* * *$ & $+* *$ & $-* * *$ \\
\hline & & & & & \\
\hline IMPORTS & Constanta & Ycap & REER & CCI & Growth \\
\hline AFTA & $-{ }^{* * *}$ & $+* * *$ & $-* * *$ & $+{ }^{*}$ & $-*$ \\
\hline EEA & $++^{* * *}$ & $+* * *$ & $-* * *$ & $+* * *$ & 0 \\
\hline LAIA & $-* *$ & $+* * *$ & $-* * *$ & $+* * *$ & $-+^{* * *}$ \\
\hline
\end{tabular}

Source: Authors' results. *sig. $<20 \%$; **sig. $<10 \%$; $* * *$ sig. $<5 \%$.

Although both affect export performance, the weaker REER in AFTA increased exports there, while the strengthening REER increased exports in the EEA and LAIA. In EEA countries, having a high level of competitiveness (Comptv) has a significant effect on export performance, while innovation (Innov) has a less significant effect, which is probably because not all countries in the EEA have high innovation scores. In AFTA countries, innovation (Innov) was found to have a moderate effect, while competitiveness was shown to have no effect on export performance, because only Singapore has high competitiveness, while other AFTA countries are not very competitive. In LAIA, the opposite was observed, that competitiveness was found to have a significant effect on export performance, whereas a low level of innovation was not shown to affect exports.

The influences of the variables studied are related to export performance in AFTA countries. This is in accordance with previous studies which showed that export activities are influenced by the exchange rate. Nishimura and Sun (2018) explained that China's performance in exporting goods and services to the European region during the reform period was only influenced by the EUR to RMB exchange rate per se and not due to its volatility. This is understandable because the exchange rate between the Chinese currency and Euro is low, so Chinese products are cheap in the European region.

Meanwhile, the effect of the number of products manufactured on export performance shown in this study is similar with the situation in China in the past two decades, where the output of the manufacturing industry in China in the early era of openness rose significantly, resulting in an economic growth rate of more than $15 \%$ and subsequently causing China's export performance to increase greatly. This is consistent with the results of Guan and Ma (2003), who stated that three company characteristics that can affect export performance are the domestic market share, size, and productivity growth rate.

Some researchers claim that there is an effect of innovation on exports (Cassiman \& Golovko, 2011), and some even claim that innovation and exports have reciprocal influences on each other (Filipescu, Prashantham, Rialp, \& Rialp, 2013). The intended innovation can be in the form of product innovation or export market innovation (Geldres-Weiss, Uribe-Bórquez, Coudounaris, \& Monreal-Pérez, 2016). However, in this study, the level of innovation was only found to have a slight effect on export 
performance in the AFTA and EEA. As for competitiveness, although some researchers state that the technological competitiveness of products, the competitiveness of value chains, and the cost competitiveness affect export performance (Chen et al., 2020), export performance in AFTA countries is not affected by competitiveness, while the effect of competitiveness on LAIA export performance is also small, and only competitiveness in the EEA has an effect on export performance.

Still, as shown in the same table, import performance in AFTA and LAIA countries tended to decline, and in EEA countries, it tended to increase. The main factors affecting import performance in the three regions are the GDP per capita (YCap) and REER, but different trends were shown for the REER. This means that if imports in AFTA and LAIA decline despite a rise in the GDP per capita, it is possible that the demand for products will be met through domestic products, so the import demand decreases. This is also supported by an increase in the consumer confidence index which has been quite significant in LAIA regions. The effect of the GDP per capita in each of the regions studied is consistent with the results of Markusen's research (2013), which showed that an equal per capita income has a positive effect on international trade, while differences in per capita income have a negative effect on international trade. Meanwhile, related to the effect of the real exchange rate (REER) on imports, the strengthening of the REER in EEA countries increases the value of imports, while in AFTA and LAIA, if the REER becomes weaker or constant, then imports will fall further.

In general, the average levels of export and import performance in the EEA, AFTA, and LAIA up to 2019 were low and tended to stagnate and decline in 2019. Several factors have been shown to affect export and import performance, but others have no impact or have a weak impact on export/import performance (Table 4). Apart from being influenced by the factors proven in this study, the less optimal performance of exports and imports in three areas is likely to be influenced by the decline in global economic growth, which has been particularly influenced by China's continued decline in economic growth. Based on World Bank data, China's GDP growth continues to decline, as follows: 10.6\% (2010), 9.5\% (2011), 7.9\% (2012), 7.8\% (2013), 7.3\% (2014), 6.9\% (2015), 6.7\% (2016), 6.8\% (2017), 6.6\% (2018), $6.1 \%$ (2019), 2.3\% (2020). Economic growth in China is largely influenced by exports and imports, and based on China's Customs Administration data, in December 2018, the level of exports in dollars fell by $4.4 \%$ compared with that in the same month a year earlier, while the level of imports fell by $7.6 \%$ in the same period. The declines in exports and imports were the worst since 2016. These declines continued with the start of the US-China trade war in mid-2019 and were exacerbated by the worldwide crisis due to the Covid-19 pandemic in 2020.

\section{CONCLUSION}

Export and import performance in the three free trade areas (AFTA, EEA and LAIA) in 2011-2019 was unsatisfactory. Performance tended to be stagnant until 2018, and it decreased in 2019. Trade performance in the EEA region is higher than in AFTA and LAIA, but export performance fell in 2019, and the number of imports still increased. The number of manufactured products (Mnfac) and the real effective exchange rate (REER) are dominant factors that affect export performance in the three areas. The level of competitiveness affects the export value in the EEA, while the level of innovation is insignificant or even has no effect on export performance.

On the other hand, the number of imports in the EEA are still rising, but in AFTA and LAIA, the average number is falling. The GDP per capita and REER strongly influence import performance. In EEA and LAIA, consumer confidence (CCI) affects import performance, but its influence is less significant in AFTA. Economic growth has a significant effect on LAIA's import demand, but in AFTA, the effect is less significant, and in EEA, it has no effect on import demand. 
Going forward, export and import performance will still be influenced by global trade performance, particular by economic growth in China and the US, as well as by the successful handling of the Covid-19 pandemic.

We suggest that other variables are investigated in further research, because in this study, several variables with a weak or even no effect on import performance were included. By replacing these with more appropriate variables, the factors that cause a less than optimal trading performance can be identified.

\section{ACKNOWLEDGEMENT}

The author thanks the Faculty of Economics, Universitas Negeri Jakarta, Indonesia for the financial support they gave to this research project.

\section{REFERENCES}

Adewuyi, A. O. (2016). Determinants of import demand for non-renewable energy (petroleum) products: Empirical evidence from Nigeria. Energy Policy, 95, 73-93.

Ang, J. B., Madsen, J. B., \& Robertson, P. E. (2015). Export performance of the Asian miracle economies: The role of innovation and product variety. Canadian Journal of Economics/Revue Canadienne d'économique, 48(1), 273-309.

Asteriou, D., Masatci, K., \& Pilbeam, K. (2016). Exchange rate volatility and international trade: International evidence from the MINT countries. Economic Modelling, 58, 133-140.

Bhat, S., \& Momaya, K. S. (2020). Innovation capabilities, market characteristics and export performance of EMNEs from India. European Business Review.

Cassiman, B., \& Golovko, E. (2011). Innovation and internationalization through exports. Journal of International Business Studies, 42(1), 56-75.

Cerra, M. V., \& Saxena, M. S. C. (2017). Booms, crises, and recoveries: A new paradigm of the business cycle and its policy implications: International Monetary Fund.

Chen, J., Chen, D., \& Yao, A. (2020). Trade development between China and countries along the Belt and Road: A spatial econometric analysis based on trade competitiveness and complementarity. Pacific Economic Review, 25(2), 205-227.

Constantinescu, C., Mattoo, A., \& Ruta, M. (2015). The global trade slowdown: cyclical or structural? : The World Bank.

Del Rio-Chanona, R. M., Mealy, P., Pichler, A., Lafond, F., \& Farmer, J. D. (2020). Supply and demand shocks in the COVID-19 pandemic: An industry and occupation perspective. Oxford Review of Economic Policy, 36(Supplement_1), S94-S137.

Doulos, D., Katsaitis, O., \& Zombanakis, G. (2020). Is the emphasis on unit labour costs an effective exportpromoting policy? A comparison between Greece and Portugal. Eurasian Economic Review, 10(3), 393-410.

Falk, M., \& de Lemos, F. F. (2019). Complementarity of R\&D and productivity in SME export behaviour. Journal of Business Research, 96, 157-168.

Filipescu, D. A., Prashantham, S., Rialp, A., \& Rialp, J. (2013). Technological innovation and exports: unpacking their reciprocal causality. Journal of International Marketing, 21(1), 23-38.

Fugazza, M., \& Hoffmann, J. (2017). Liner shipping connectivity as determinant of trade. Journal of Shipping and Trade, 2(1), 1-18.

Geldres-Weiss, V. V., Uribe-Bórquez, C. T., Coudounaris, D. N., \& Monreal-Pérez, J. (2016). Innovation and experiential knowledge in firm exports: Applying the initial U-model. Journal of Business Research, 69(11), 50765081.

Grimme, C., Lehmann, R., \& Noeller, M. (2021). Forecasting imports with information from abroad. Economic Modelling, 98, 109-117.

Grossman, G. M. (2016). The purpose of trade agreements. In Handbook of commercial policy (Vol. 1, pp. 379-434): Elsevier. 
Guan, J., \& Ma, N. (2003). Innovative capability and export performance of Chinese firms. Technovation, $23(9), 737$ 747.

Gujarati, D. (2012). Econometrics by example. NY: Macmillan.

Haberler, G. (2017). Prosperity and depression: A theoretical analysis of cyclical movements: Routledge.

Hanson, G. H., Robertson, R., \& Brambilla, I. (2010). 4. China and the Manufacturing Exports of Other Developing Countries: University of Chicago Press.

Hong, G. H., Lee, J., Liao, W., \& Seneviratne, D. (2017). China and Asia in global trade slowdown. Journal of International Commerce, Economics and Policy, 8(01), 1750001.

Itakura, K. (2020). Evaluating the impact of the US-China trade war. Asian Economic Policy Review, 15(1), 77-93.

Karagöz, K. (2016). Determining factors of 'Turkey's export performance: An empirical analysis. Procedia economics and finance, 38, 446-457.

Kim, C. B. (2017). Does exchange rate volatility affect Korea's seaborne import volume? The Asian Journal of Shipping and Logistics, 33(1), 43-50.

Lewis, L. T., \& Monarch, R. (2016). Causes of the global trade slowdown. Retrieved from (No. 2016-11-10). Board of Governors of the Federal Reserve System (US).

Liau, V. E., \& Geetha, C. (2020). An empirical evidence on the impact of real effective exchange rate on trade balance. Malaysian Journal of Business and Economics (MJBE), 51-51.

Lipsey, R. E., Blomström, M., \& Kravis, I. B. (2019). R®D by multinational firms and host country exports. British: Routledge.

Markusen, J. R. (2013). Putting per-capita income back into trade theory. Journal of International Economics, 90(2), 255265.

Mohanty, S., \& Sethi, N. (2019). Does inward FDI lead to export performance in India? An empirical investigation. Global Business Review, 0972150919832770.

Mukhtarov, S., Alalawneh, M. M., Ibadov, E., \& Huseynli, A. (2019). The impact of foreign direct investment on exports in Jordan: An empirical analysis. Journal of International Studies, 12(3), 38-47.

Nishimura, Y., \& Sun, B. (2018). China's exchange-rate regime reform and trade between China and the Eurozone. Emerging Markets Finance and Trade, 54(2), 450-467.

Pascucci, F. (2018). The export competitiveness of Italian coffee roasting industry. British Food Journal.

Romero, J. P., \& McCombie, J. S. (2018). Thirlwall's law and the specification of export and import functions. Metroeconomica, 69(2), 366-395.

Ruzekova, V., Kittova, Z., \& Steinhauser, D. (2020). Export Performance as a Measurement of Competitiveness. Journal of Competitiveness, 12(1), 145.

Safeer, A. A., He, Y., Abrar, M., \& Ullah, A. (2019). Diagnostics of the challenges and potential solutions to improve export competitiveness in international markets: The case of Pakistani readymade garments industry. Journal of Competitiveness, 11(3).

Taylor, A. M., \& Taylor, M. P. (2004). The purchasing power parity debate. Journal of economic perspectives, 18(4), 135158.

Whalley, J. (2007). 3. Why Do Countries Seek Regional Trade Agreements?. University of Chicago Press. 